\title{
Kitap İncelemesi: Bir Değer ve Eğitim Merkezi Olarak Aile
}

\section{Rabia GÜRBÜZ}

Psikolojiden sosyolojiye, eğitimden felsefeye kadar çok geniş alanlarda üzerinde durulan ve tanımı yapılan değer kavramını kısaca kişinin kendisi ve çevresine yönelik geliştirdiği inançlar bütünüdür şeklinde tanımlamak mümkündür. Her kişide ve her toplumda farklılık gösteren değer olgusu özellikle son yıllarda ülkemizde de üzerinde durulan ve önem verilen bir konu olmuştur.

Bireylere küçük yaşlardan itibaren verilen eğitim, ilerleyen yaşamını da şekillendirmektedir. Okul döneminde verilen değer eğitiminin önemli olduğu ve bu konuda daha planlı bir yol haritası çizildiğini söylemek mümkündür. Ancak göz ardı edilmemesi gereken noktalardan biri ailede verilen değer eğitimidir. Bireyin küçük yaşlarda ailesinden aldığı eğitim ve toplum bilinci tüm yaşamını etkilemektedir. "Bir Değer ve Eğitim Merkezi Olarak Aile" kitabı bu konuya ışık tutmak amacıyla okuyucuya sunulmuştur.

Pegem Yayınevi'nden çıkan eser, Sakarya Üniversitesi Eğitim Fakültesi öğretim üyelerinden Doç. Dr. Halil İbrahim Sağlam tarafından kaleme alınmıştır. Ailede verilen değerler eğitimi üzerine değerli bilgilerin okuyucuyla paylaşıldı̆̆ kitap 72 sayfadan ve üç bölümden oluşmaktadır. Tüm bölümlerin sonunda bölümün ana hattını çizen ve önemli noktaları tekrar hatırlatan özet başlığı bulunmaktadır.

Kitabın ilk bölümü "Değer" başlı̆ı altında oluşturulmuştur. Değer üzerine kuramsal bilgilerin verildiği kısa bir giriş ile bölüm başlamaktadır. Değer üzerine yapılan çeşitli tanımlardan sonra değerin ilişkili olduğu diğer kavramlar üzerinde durulmuştur. Bu kavramlardan ilki “Değer-Tutum illişkisi" başlığı altında okuyucu ile paylaşılmış ve değer ile tutum kavramları arasındaki kapsayıcı olan noktalar ve farklılıklar belirtilmiştir. "Değer-Inanç ilişkisi" ve "Değer-Norm ilişkisi" alt başlıklarında da yine kavramlar arasındaki ayrımlar üzerinde durulmuştur. "Değerlerin İşlevleri" ve bireylerin ilk çocukluktan itibaren ailevi ve toplumsal değerlerin yanı sıra dini ve evrensel değerleri de kazanma süreci üzerine bilgilerin verildiği “Değer Kazanma Süreci” alt başlıklarına yer verilmiş, "Değerlerin Sınıflandırııması" başlığı ile bölüm sonlandırıımıştır.

"Bir Değer Olarak Aile" başlıklı ikinci bölümde değerler eğitimi bağlamında ailede değer eğitimine yer verilmiştir. Bilindiği gibi bireyin hem fiziksel hem de duygusal anlamda ilk intiyaçları aile tarafından karşılanmaktadır ve bu durum bireyin kişiliğinin şekillenmesinde ailenin öneminin ne denli büyük olduğunu göstermektedir. Eserde de bu nokta üzerinde durulmuş ve genel çerçevede aile değerleri hakkında bilgi verilmiştir. Yine eserde aile değerleri "saygı", "sevgi", "sabır", "sadakat", "sorumluluk" ve "hoşgörü" alt başlıklarında ele alınmıştır. Aile değerlerinin ardından bölüm "Aile ve İşlevleri" alt başlığı ile devam etmektedir. Bu başlıkta aile birliği hakkında giriş yapılarak bilgi verilmekte, kişiliğin oluşması ve toplumda birey olarak var olmanın temellerinin ailede oluştuğu vurgusu yapılmaktadır. "Bir Değer Eğitim Merkezi Olarak Aile" alt başlığında ise anne ve babanın çocuğun değer gelişimi üzerinde etkisine yer verilmiş ve ailelerin değer aktarımı konusunda dikkat etmesi gereken hususlar üzerinde durulmuştur.

Kitabın son bölümü olan üçüncü bölüm "Bir Değer Olarak Aileye Yönelik Tehditler" başlığını taşımaktadır. Bölümün giriş kısmında kısaca aileyi tehdit eden unsur üzerinde durulmuş ve detaylı bilgiler alt başlıklarda ele alınmıştır. "Ailenin Değişimi" alt başlı̆ıında ailelerin geniş aile statüsünden

\footnotetext{
*Ars. Gör., Eskişehir Osmangazi Üniversitesi, Eğitim Fakültesi, Sosyal Bilimler ve Türkçe Eğitimi Bölümü, Türkçe Eğitimi Bölümü, prgurbuz@gmail.com. 
çekirdek aileye veya tek ebeveynli aile dönüşümleri ya da ailelerin tek çocuklu oluşu üzerinde durulmuş ve bu durumun getirdiği sonuçlara değinilmiştir. "Aile Değerlerinden Uzaklaşılması" alt başlığında aile bireyleri arasında sadakatten uzaklaşma ve güven sorunu sonucu oluşabilecek tehditlere, "Aile iç̧i Şiddet" alt başlığında ise fiziksel, psikolojik yahut daha farklı şekilde meydana gelen şiddet konusuna yer verilmiştir. "Bağımlılıklar" başlı̆ında aile bireylerinin alkol, sigara, uyuşturucu gibi bağımlılık yaratabilecek maddelerin kullanımının aile üzerindeki etkisine değinilmiştir. "Tüketerek Tükenmek" alt başlığında sanayileşme ve modernleşme ile birlikte mal ve hizmet tüketiminin de hızlandı̆̆ından söz edilmiş ve yine bu durumun aile üzerindeki olumsuz etkileri hakkında bilgi verilmiştir. Son alt başık olan "Sosyal Medyanın Gizemine Aldanmak" başlığında ise bilim ve teknolojinin gelişime eş olarak artan sosyal medya kullanımının aileye yönelik tehditlerinden bahsedilmiştir. iç̧inde bulunduğu toplumun gelişmesine katkıda bulunan aile ve ailede verilen değer eğitimi üzerine bilgilerin yer aldığı ve önemli noktalara değinilen eserin, hem bu alanla ilgilenen akademisyen, öğretmen ve öğrencilerin hem de anne ve babaların başvuracağı iyi bir yol gösterici olacağı düşünülmektedir.

Incelenen Kitap:

SAĞLAM, H. İ. (2017). Bir Değer ve Eğitim Merkezi Olarak Aile. (1. Baskı). Ankara: Pegem Akademi. 